\title{
Mercury bioaccumulation by Suillus bovinus mushroom and probable dietary intake with the mushroom meal
}

\author{
Martyna Saba $^{1} \cdot$ Jerzy Falandysz $^{1} \cdot$ Innocent C. Nnorom $^{2}$
}

Received: 5 January 2016 / Accepted: 23 March 2016/Published online: 12 April 2016

(C) The Author(s) 2016. This article is published with open access at Springerlink.com

\begin{abstract}
This paper reports the results of the study of the efficiency of accumulation and distribution of mercury $(\mathrm{Hg})$ in the fruiting bodies of fungus Suillus bovinus and the probable dietary intake of $\mathrm{Hg}$ and the potential health risk. Fungal fruiting bodies and soil materials were collected from 13 background areas in the northern part of Poland between 1993 and 2013. Mercury in the caps of fruiting bodies varied from 0.10 \pm 0.06 to $0.79 \pm 0.40 \mathrm{mg} \mathrm{kg}^{-1}$ dry biomass and in the stipes from $0.083 \pm 0.028$ to $0.51 \pm 0.22 \mathrm{mg} \mathrm{kg}^{-1}$ dry biomass. The mean values of cap to stipe $\mathrm{Hg}$ content quotient varied from $1.3 \pm 0.2$ to $2.6 \pm 0.6$. The $\mathrm{Hg}$ content in the upper $0-10 \mathrm{~cm}$ layer of soil substrate varied from $0.015 \pm 0.004$ to 0.031 $\pm 0.019 \mathrm{mg} \mathrm{kg}^{-1}$ dry biomass. S. bovinus could be considered as an efficient accumulator of $\mathrm{Hg}$, at least from low level polluted soils, and the values of $\mathrm{Hg}$ bioconcentration factor (BCF) varied from $6.4 \pm 2.2$ to $45 \pm 20$ for caps and from 3.8 \pm 1.4 to $29 \pm 11$ for stipes. A conventional meal $(300 \mathrm{~g}$ ) portion of $S$. bovinus foraged from background areas provides $\mathrm{Hg}$ dose far below the provisionally tolerable weekly intake or recommended reference dose set for this element by authorities. An examination of published data on $\mathrm{Hg}$ in fruiting bodies of fungi genus Suillus showed low contamination of specimens foraged from background areas. Also reviewed are published data on $\mathrm{Hg}$ in fungi genus Suillus collected worldwide.
\end{abstract}

Responsible editor: Philippe Garrigues

Innocent C. Nnorom

chidiabsu@yahoo.co.uk

1 Laboratory of Environmental Chemistry and Ecotoxicology, Gdańsk University, 63 Wita Stwosza Str., 80-308 Gdańsk, Poland

2 Environmental Chemistry Unit, Department of Industrial Chemistry, Abia State University, Uturu, Abia State, Nigeria
Keywords Forest $\cdot$ Fungi $\cdot$ Heavy metals $\cdot$ Suillus mushroom · Organic food $\cdot$ Soil

\section{Introduction}

Mercury along with other elements such as arsenic, lead, and cadmium are important to consider in terms of food chain contamination (McLaughlin et al. 1999). The past two to three decades have witnessed increasing publications evaluating the $\mathrm{Hg}$ levels in foods and the environment at state and regional levels. However, the recent publication of the United Nations Environment Programme indicated that this concern is a global issue as these contaminations result more from anthropogenic emissions of Hg (UNEP 2013). The increasing environmental $\mathrm{Hg}$ contamination could be attributed to the unique properties of $\mathrm{Hg}$ - its low vapor pressure (elemental $\mathrm{Hg}$ ) and the persistency of the vapors. Studies have reported longrange transportation of $\mathrm{Hg}$ at a global scale and deposition of airborne anthropogenic $\mathrm{Hg}$ at remote regions (Demers et al. 2007). Elevated amounts of mercury have been observed in mushrooms Gymnopus erythropus (Pers.) Antonín, Halling \& Noordel. and Marasmius dryophilus (Bull.) Murrill which depend on litter as source of food, in remote regions of the Minya Konka (Mt. Gongga) in the Eastern Tibetan Plateau-a site located very far from industrial sources of $\mathrm{Hg}$ emissions and other saprophytic species such as Agaricus arvensis Schaeff., Agaricus maleolens F.H. Møller (current name Agaricus bernardii Quél.), and Coprinus comatus (O.F. Müll.) Pers. from contaminated urban grounds (Falandysz 2016, Falandysz et al. 2014a, Svoboda and Kalač 2003).

Mercury as a trace element is natural and ubiquitous, in the lithosphere and hydrosphere, with predilection to combine with sulfur (S) and selenium (Se) in the environment, consequent upon which it occurs in foods and feedstuff. Mercury is 
readily biomethylated into methylmercury, which is then bioaccumulated (usually together with $\mathrm{Se}$ for which $\mathrm{MeHg}$ is an antagonist in selenocysteine) up the aquatic food chain (Ralston and Raymond 2010). Differences in $\mathrm{Hg}$ contents of soils is due to airborne $\mathrm{Hg}$ pollution (accumulation in litter and organic layer of soils) or from geogenic $\mathrm{Hg}$ (which occurs under the organic horizon layer). Mercury availability to the mycelia, genetic factor, and adaptation to the geochemical composition and anomalies of soil background could be important variables that determine the amounts of $\mathrm{Hg}$ observed in mushrooms - as could be observed in several studies (Árvay et al. 2014; Crane et al. 2010; Falandysz 2014; Falandysz and Bielawski 2001, 2007; Falandysz and Drewnowska 2015; Falandysz et al. 2012a, 2012b, 2014b, 2015a; Krasińska and Falandysz 2015, 2016; Kojta et al. 2012, 2015; Wiejak et al. 2014).

Mushrooms foraged from the woodlands and pastures are simple organic foods or food ingredients that are valued worldwide because of their unique taste, fragrance, texture, and contents of basic nutrients (proteins, minerals etc.). Mushrooms are also rather low in fresh product as their moisture content is about $90 \%$ (Falandysz and Borovička 2013). In the modern times some probiotic features (largely antioxidants content etc.) of crude mushrooms have been highlighted (Sarikurkcu et al. 2015). Another particular feature of mushrooms collected in the wild, which can be species-specific, is the abundance of trace elements and minerals, including those toxic to mammals as well as the specific ability of certain species to efficiently accumulate radiocesium $\left({ }^{134 / 137} \mathrm{Cs}\right)$ from radioactive fallout (Chojnacka et al. 2012; Falandysz and Brzostowski 2007; Falandysz et al. 1994; 2015b and 2015c; Karadeniz and Yarpak 2010; Tel et al. 2014). Mercury is an element that is known to be hazardous to man in any of its physical and chemical forms, and in mushrooms, inorganic mercury is the dominant form while methylmercury is a minor constituent (Rieder et al. 2011).

Both the mycorrhizal and non-mycorrhizal mushrooms are efficient in mobilizing and subsequently sequestering $\mathrm{Hg}$ and other elements from soil/litter substratum into their fruiting bodies (Chudzyński et al. 2009, 2011; Drewnowska et al. 2012, 2014; Falandysz et al. 1996; Mleczek et al. 2015; Nasr and Arp 2011; Nasr et al. 2012). The mushroom mycelia can very efficiently mobilize $\mathrm{Hg}$ from mushroom substratum (soil, litter, or wood) and translocate the same to the mushroom fruiting bodies thereby resulting in the observation of elevated amounts of $\mathrm{Hg}$ in the morphological parts of the mushroom (the cap and stipe) compared to the $\mathrm{Hg}$ levels in the substrate in some cases (Falandysz et al. 2013; Melgar et al. 2009; Tüzen et al. 1998). Studies have shown a very wide variation in the ability (efficiency) of different mushroom species to accumulate $\mathrm{Hg}$ (and other heavy metals such as $\mathrm{Pb}$ and Cd) (Alonso et al. 2000; Brzostowski et al. 2011; Falandysz et al. 2001a, 2001b, 2003a, 2003b, 2003c, 2003d, 2007; Falandysz and Gucia 2008; Gucia et al. 2012; Vetter and Berta 1997). The observed variations in metal contents of mushrooms as reported in literature have been attributed to several factors by different authors, including geochemical and biochemical factors (e.g., trace element bioavailability in soils, growing period, and age of mycelium). Unfortunately, till date, the roles of these factors and other possible cofounding variable are not very well understood. Mushrooms' ability to accumulate $\mathrm{Hg}$ is readily estimated by calculating the bioconcentration factor (BCF) - which is usually evaluated to understand the bioconcentration potential of the elements by any given species.

The BCF is a quotient of the $\mathrm{Hg}$ content of the mushroom fruiting bodies to that of the substrate. Higher BCF indicates accumulation of the elements of the substrate or soils by the mushroom. Studies have reported BCF of more than 1 for many elements in several species of mushroom. A low BCF value $(\mathrm{BCF}<1)$ can indicate low potential of the mushroom species to accumulate a given element or a low bioavailability of the element contained in the substratum whereas a high $\mathrm{BCF}$ will show that the metal under consideration is bioaccumulated by the mushroom.

For contaminants that accumulate in the body over time such as lead, cadmium, dioxin, and mercury, the provisional tolerable weekly intake (PTWI) or monthly intake (PTMI) are used as reference values in evaluating the risks of intake of such toxic metals from food consumption. Thus, in evaluating the intake of contaminants that accumulate in the body over time (such as $\mathrm{Hg}$ ) from food and foodstuff, the PTWI or PTMI of $\mathrm{Hg}$ is usually used as a reference in estimating and evaluating possible risks from intakes of contaminants from food consumption. The Hg PTWI value which was $0.005 \mathrm{mg} \mathrm{Hg}$ $\mathrm{kg}^{-1}$ bm between 1978 and 2010 was reviewed downwards to $0.004 \mathrm{mg} \mathrm{Hg} \mathrm{kg}^{-1} \mathrm{bm}$ in 2010 based on the assumption that the predominant form of $\mathrm{Hg}$ in foods, other than fish and shellfish, is inorganic Hg (JECFA 2010). Similarly, in estimating non-carcinogenic health effects of $\mathrm{Hg}$, a reference dose (RfD) of $0.0003 \mathrm{mg} \mathrm{Hg} \mathrm{kg}{ }^{-1}$ bm daily is commonly used (US EPA 1987).

This paper reports the results of the investigation of the extent of $\mathrm{Hg}$ contamination and bioconcentration of Suillus bovinus mushroom collected from forested areas of Poland over a period of about two decades. This study also estimated $\mathrm{Hg}$ intake and evaluated the potential human health risk from the consumption of $S$. bovinus collected from within the localities studied thereby providing information necessary in evaluating the likely toxicological implications of the consumption of $S$. bovinus mushroom. Also presented is a review and comparative analysis of $\mathrm{Hg}$ in Suillus mushrooms. 


\section{Materials and methods}

\section{Sample collection and preservation}

During the mushroom collection season in 1993-2013, 586 individual fruiting bodies of $S$. bovinus mushroom were collected from 13 spatially distant places in Poland (Fig. 1). On collecting the mushroom fruiting bodies, the topsoil layer of the forests $(0-10 \mathrm{~cm})$ beneath the fruiting bodies were also collected for most of the places studied. The samples were collected from such places in Poland as the Darżlubska Wilderness in Krokowa region, Nearshore Landscape Park, the Studnia river Valley in the region of Kepice, outskirts of the Sulecczyno place in Kaszuby land, from several regions of the Tuchola Pinewoods complex and the forests in the outskirt of Kaszuny and Szczytno in the Warmia and Mazurian lands, Lipowiec Kościelny and Kościelna Wieczfnia in Mazovia land, and Ciechocinek in Kujawy land (Fig. 1, Table 1).

All individual fruiting bodies selected for this study were mature and in good body condition (not infected by insects). The mushroom fresh fruiting bodies were cleaned up from any visible plant vegetation and soil debris with a plastic knife. To get insight into the distribution of $\mathrm{Hg}$ between the two major morphological parts of the fruiting bodies of mushrooms, the individual mushrooms from several places were separated into cap (with skin) and stipe. Next, the individual cap and stipe samples were sliced using a plastic knife and dried separately or in a pool accordingly (Falandysz 2014). Thereafter, for drying, the mushroom samples were placed into a plastic basket of the electrically heated commercial dryer for vegetables and dried at $65{ }^{\circ} \mathrm{C}$ to constant mass. Dried fungal materials

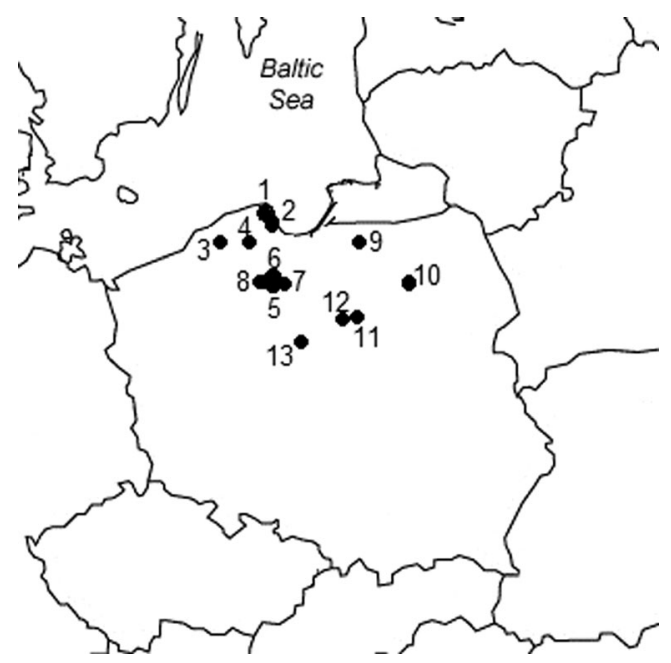

Fig. 1 Localization of the sampling places of S. bovinus in Poland (1-13; for details, see Table 1) (1 Darżlubska Wilderness, 2 Nearshore Landscape Park, 3 Studnica River Valley, Kępice, 4 Sulęczyno, 5 Tuchola Pinewoods, Łuby, 6 Tuchola Pinewoods, Osowo Leśne, 7 Tuchola Pinewoods, Lubichowo, 8 Tuchola Pinewoods, 9 Kaszuny, 10 Szczytno, 11 Kościelna Wieczfnia, 12 Lipowiec Kościelny, 13 Ciechocinek) were pulverized in a porcelain mortar and kept in brand new sealed polyethylene bags under dry conditions. The soil samples, free of any visible organisms, small stones, sticks, and leaves were air dried at room temperature for several days under clean conditions and further dried at $65^{\circ} \mathrm{C}$ to constant mass. Next, the soil samples were ground in a porcelain mortar, sieved through a pore size of $2-\mathrm{mm}$ plastic sieve, and thereafter stored in brand new sealed polyethylene bags under dry conditions.

Double distilled water was used in all preparations. Mercury standard solution of $1.0 \mathrm{mg} \mathrm{mL}^{-1}$ was obtained from the $10 \mathrm{mg} \mathrm{mL}^{-1}$ standard stock solution. Blank and 100, 150, and $200 \mu \mathrm{L}$ of $1.0 \mathrm{mg} \mathrm{mL}^{-1} \mathrm{Hg}$ standard solutions were injected into the analyzer for the construction of a calibration curve, which was prepared new each week.

\section{Sample analyses}

The determinations of total $\mathrm{Hg}$ content of fungal and soil samples was performed using cold vapor atomic absorption spectroscopy (CV-AAS) by a direct sample thermal decomposition coupled with gold wool trap of $\mathrm{Hg}$ and its further desorption and quantitative measurement at wavelength of $296 \mathrm{~nm}$. The analytical instrument used was mercury analyzer (MA-2000, Nippon Instruments Corporation, Takatsuki, Japan) equipped with auto sampler and operated respectively at low and high modes (Jarzyńska and Falandysz 2011; Nnorom et al. 2013).

A running analytical control and assurance quality ( $\mathrm{AC} /$ AQ) was performed through the analysis of blank samples and certified fungal reference materials produced by the Institute of Nuclear Chemistry and Technology, Warsaw, Poland. The declared content of Hg for material CS-M-1 (dried mushroom powder S. bovinus) is $0.174 \pm 0.018$ $\mathrm{Hg} \mathrm{mg} \mathrm{kg}{ }^{-1} \mathrm{db} \mathrm{Hg}$, and our result $(n=13)$ was 0.185 $\pm 0.011 \mathrm{mg} \mathrm{kg}^{-1} \mathrm{db}$; for CS-M-2 (dried mushroom powder Agaricus campestris), the declared $\mathrm{Hg}$ content is 0.164 $\pm 0.004 \mathrm{Hg} \mathrm{mg} \mathrm{kg}^{-1} \mathrm{db}$ and our result $(n=8)$ was 0.165 $\pm 0.005 \mathrm{mg} \mathrm{kg}^{-1} \mathrm{db}$. The limit of detection (LOD) of this study was $0.003 \mathrm{mg} \mathrm{Hg} \mathrm{kg}^{-1} \mathrm{dm}$, and the quantification limit (LOQ) was $0.005 \mathrm{mg} \mathrm{Hg} \mathrm{kg}^{-1} \mathrm{db}$. One blank sample and one certified reference material sample were examined with each set of three to five samples studied.

\section{Target hazard quotient (THQ)}

The estimated daily intake (EDI) was calculated to estimate the potential hazard from the consumption of a meal of S. bovinus using the formula:

$\mathrm{EDI}=\frac{\mathrm{Mc} \times \text { Consumption rate }}{\text { Body weight }}$ 
Table 1 Mercury in fruiting bodies of European Cow Bolete Suillus bovinus ( $\mathrm{mg} \mathrm{kg}^{-1} \mathrm{db}$ ) and values of the quotients $\mathrm{Hg}_{\mathrm{C}} / \mathrm{Hg}_{\mathrm{S}} \mathrm{Q}_{\mathrm{C} / \mathrm{S}}, \mathrm{BCF}(\mathrm{arithmetic}$ mean, standard deviation, median, and range)

\begin{tabular}{|c|c|c|c|c|c|c|}
\hline \multirow[t]{2}{*}{ Place, year, and sample size } & \multicolumn{3}{|c|}{ Mercury content (mg kg ${ }^{-1}$ dry matter) } & \multirow[t]{2}{*}{$Q_{\mathrm{C} / \mathrm{S}}$} & \multicolumn{2}{|l|}{$\mathrm{BCF}$} \\
\hline & Cap & Stipe & Soil & & Cap & Stipe \\
\hline \multirow[t]{3}{*}{ (1) ${ }^{\mathrm{a}}$ Pomerania land, Darżlubska Wilderness, 2003, $n=15^{\mathrm{b}}$} & $0.79 \pm 0.4$ & $0.51 \pm 0.22$ & $0.017 \pm 0.003$ & $1.7 \pm 1.1$ & $45 \pm 20$ & $29 \pm 11$ \\
\hline & $0.30-1.7$ & $0.14-0.88$ & $0.011-0.021$ & $1.0-5.3$ & $19-96$ & $7.2-49$ \\
\hline & 0.66 & 0.43 & 0.019 & 1.4 & 40 & 28 \\
\hline \multirow{3}{*}{$\begin{array}{l}\text { (2) Pomerania land, Nearshore Landscape Park, 2006, } \\
n=15^{\mathrm{c}}(79)^{\mathrm{d}}\end{array}$} & $0.10 \pm 0.06$ & $0.083 \pm 0.028$ & $0.016 \pm 0.007$ & $1.3 \pm 0.6$ & $8.1 \pm 4.9$ & $5.9 \pm 1.9$ \\
\hline & $0.015-0.26$ & $0.048-0.14$ & $0.0083-0.035$ & $0.17-2.5$ & $1.2-17$ & $1.9-9.5$ \\
\hline & 0.11 & 0.082 & 0.013 & 1.4 & 8.4 & 6.1 \\
\hline \multirow{3}{*}{$\begin{array}{l}\text { (3) Pomerania land, Studnica river Valley, Kępice, 2003, } \\
n=14(106)\end{array}$} & $0.41 \pm 0.30$ & $0.20 \pm 0.14$ & $0.025 \pm 0.011$ & $2.2 \pm 0.8$ & $19 \pm 16$ & $9.4 \pm 7.5$ \\
\hline & $0.098-1.3$ & $0.041-0.59$ & $0.0069-0.048$ & $0.67-4.0$ & $2.4-64$ & $1.1-30$ \\
\hline & 0.37 & 0.17 & 0.023 & 2.1 & 16 & 7.7 \\
\hline \multirow[t]{3}{*}{ (4) Pomerania land, Sulęczyno 2006, $n=15(48)$} & $0.15 \pm 0.05$ & $0.091 \pm 0.03$ & $0.025 \pm 0.006$ & $1.8 \pm 0.8$ & $6.4 \pm 2.2$ & $3.8 \pm 1.4$ \\
\hline & $0.10-0.31$ & $0.039-0.16$ & $0.015-0.033$ & $0.96-3.5$ & $4.2-10$ & $1.5-6.2$ \\
\hline & 0.13 & 0.095 & 0.026 & 1.5 & 5.8 & 3.6 \\
\hline (5) Pomerania land, Tuchola Pinewoods, Łuby 1993, $n=1(25)$ & 0.23 & & NA & NA & NA & \\
\hline \multirow{3}{*}{$\begin{array}{l}\text { (6) Pomerania land, Tuchola Pinewoods, Osowo Leśne 2006, } \\
n=15(68)\end{array}$} & $0.21 \pm 0.03$ & & $0.015 \pm 0.004$ & NA & $14 \pm 2$ & \\
\hline & $0.13-0.25$ & & $0.0095-0.021$ & & $10-19$ & \\
\hline & 0.22 & & 0.015 & & 14 & \\
\hline \multirow{3}{*}{$\begin{array}{l}\text { (7) Pomerania land, Tuchola Pinewoods, Lubichowo, 2007, } \\
n=13(27)\end{array}$} & $0.28 \pm 0.11$ & $0.17 \pm 0.07$ & $0.021 \pm 0.016$ & $1.8 \pm 0.6$ & $18 \pm 10$ & $11 \pm 7$ \\
\hline & $0.16-0.60$ & $0.063-0.29$ & $0.0090-0.065$ & $1.1-3.5$ & $4.2-38$ & $2.7-23$ \\
\hline & 0.26 & 0.15 & 0.015 & 1.6 & 19 & 10 \\
\hline (8) Pomerania land, Tuchola Pinewoods, 2011, $n=1(60)$ & 0.17 & & NA & NA & NA & NA \\
\hline (8) Pomerania, Tuchola Pinewoods, 2013, $n=1$ (62) & 0.15 & & NA & NA & NA & NA \\
\hline \multirow[t]{3}{*}{ (9) Warmia and Mazury land, Kaszuny, 2003, $n=14$} & $0.33 \pm 0.19$ & $0.16 \pm 0.10$ & $0.025 \pm 0.003$ & $2.0 \pm 0.7$ & $13 \pm 8$ & $6.6 \pm 4.2$ \\
\hline & $0.20-0.78$ & $0.070-0.49$ & $0.018-0.031$ & $1.4-4.2$ & $4.2-3.1$ & $3.0-19$ \\
\hline & 0.28 & 0.15 & 0.025 & 1.9 & 11 & 5.5 \\
\hline \multirow[t]{3}{*}{ (10) Warmia and Mazury land, Szczytno, 2003, $n=14$} & $0.20 \pm 0.04$ & $0.10 \pm 0.04$ & $0.031 \pm 0.019$ & $2.2 \pm 0.6$ & $8.6 \pm 3.8$ & $4.4 \pm 1.9$ \\
\hline & $0.13-0.26$ & $0.043-0.15$ & $0.012-0.073$ & $1.4-3.5$ & $3.3-14$ & $1.3-7.9$ \\
\hline & 0.22 & 0.088 & 0.021 & 2.0 & 9.3 & 4.7 \\
\hline \multirow{3}{*}{$\begin{array}{l}\text { (11) Mazovia land, Commune of Kościelna Wieczfnia, } \\
\text { 2006, } n=14(15)\end{array}$} & $0.11 \pm 0.03$ & $0.083 \pm 0.030$ & $0.017 \pm 0.014$ & $1.3 \pm 0.2$ & $9.4 \pm 5.6$ & $7.3 \pm 4.7$ \\
\hline & $0.056-0.18$ & $0.055-0.17$ & $0.006-0.62$ & $0.95-1.8$ & $1.4-20$ & $1.0-15$ \\
\hline & 0.11 & 0.080 & 0.013 & 1.3 & 7.1 & 5.2 \\
\hline \multirow[t]{3}{*}{ (12) Mazovia land, Lipowiec Kościelny, 2006, $n=15(20)$} & $0.38 \pm 0.18$ & $0.16 \pm 0.13$ & $0.027 \pm 0.012$ & $2.6 \pm 0.6$ & $19 \pm 14$ & $7.4 \pm 5.4$ \\
\hline & $0.19-0.99$ & $0.07-0.61$ & $0.01-0.04$ & $1.6-4.0$ & $8.0-50$ & $2.4-19$ \\
\hline & 0.37 & 0.15 & 0.03 & 2.5 & 12 & 5.1 \\
\hline \multirow[t]{3}{*}{ (13) Kujawy land, Ciechocinek, 2004, $n=15(33)$} & $0.26 \pm 0.06$ & $0.18 \pm 0.04$ & $0.026 \pm 0.004$ & $1.5 \pm 0.3$ & $10 \pm 3$ & $6.8 \pm 2.0$ \\
\hline & $0.20-0.38$ & $0.12-0.25$ & $0.018-0.032$ & $1.1-2.2$ & $6.7-16$ & $4.1-10$ \\
\hline & 0.24 & 0.17 & 0.026 & 1.5 & 9.2 & 6.6 \\
\hline
\end{tabular}

${ }^{a}$ Place (see Fig. 1)

${ }^{\mathrm{b}}$ Number of individuals

${ }^{\mathrm{c}}$ Number of composite samples

${ }^{\mathrm{d}}$ Number of individuals in a pool (in parentheses)

where $\mathrm{Mc}$ is the $\mathrm{Hg}$ content of the mushroom ( $\mathrm{mg} \mathrm{kg}^{-1}$, fresh weight), consumption rate of $100 \mathrm{~g} \mathrm{day}^{-1}$ and $300 \mathrm{~g} \mathrm{day}^{-1}$ for average level consumer (ALC) and a high level consumer (HLC), respectively, while the body weight for ALC was $30 \mathrm{~kg}$ and that of HLC is $70 \mathrm{~kg}$.
Similarly, to assess the long-term potential health risks associated with $\mathrm{Hg}$ intakes from consumption of S. bovinus, the target hazard quotients (THQ) was calculated to evaluate the non-carcinogenic health risk. The THQ is often used in evaluating potential risks for $\mathrm{Hg}$ (as well as other heavy metals) 
intakes from contaminated foods. THQ was proposed by the USEPA (USEPA 2000). THQ values greater than 1 indicates that the consumption of contaminated foods is likely to expose the consumer to risks that could result in deleterious effects. In this study, non-cancer risk assessment of $\mathrm{Hg}$ exposure from consumption of $S$. bovinus was evaluated based on the use of THQ which is a ratio between the estimated dose of contaminant $\mathrm{Hg}$ and the reference dose below which there will not be any appreciable risk. The method used for the evaluation of THQ is described by the equation below (Chien et al. 2002; US EPA 2000; Wang et al. 2005).

$\mathrm{THQ}=\frac{E_{\mathrm{F}} E_{\mathrm{D}} F_{\mathrm{IR}} C}{\operatorname{RfD}_{\mathrm{o}} W_{\mathrm{AB}} T_{\mathrm{A}}} \times 10^{-3}$

$E_{\mathrm{F}}$ is the exposure frequency (365 days year $\left.{ }^{-1}\right) ; E_{\mathrm{D}}$ is the exposure duration (70 years), equivalent to the average lifetime (Bennett et al. 1999); $F_{\mathrm{IR}}$ is the mushroom ingestion rate (g person day ${ }^{-1}$ ), assuming $300 \mathrm{~g}$ fresh mushroom consumption for HLC (adults) and $100 \mathrm{~g}$ for ALC (children); $C$ is the average $\mathrm{Hg}$ content in mushroom ( $\mathrm{mg} \mathrm{kg}^{-1}$ wet weight); RfDo is the mercury oral reference dose $\left(0.0005 \mathrm{mg} \mathrm{kg}^{-1}\right.$ day $\left.{ }^{-1}\right)$ (US EPA 1997); $W_{\mathrm{AB}}$ is the average body weight (70 kg for a HLC and $30 \mathrm{~kg}$ for ALC), and $T_{\mathrm{A}}$ is the averaged exposure time for non-carcinogens (365 days year ${ }^{-1} \times E_{\mathrm{D}}$, assuming 70 years for HLC and 30 years for ALC). An index more than 1 is considered as not safe for human health (USEPA 2002), and this indicates that it is likely that the consumer of the contaminated food may experience deleterious effects. The higher the THQ, the higher the chances of risk to the exposed population.

\section{Results and discussion}

\section{Hg in mushroom cap and stipe}

The mercury contents of the caps and stipes of $S$. bovinus mushroom and the soils beneath fruiting body as well as the values of the quotients of $\mathrm{Hg}$ content of cap to stipe $\left(Q_{\mathrm{C} / \mathrm{S}}\right)$ and the quotient of $\mathrm{Hg}$ in cap/stipe to $\mathrm{Hg}$ in soil substratum $(\mathrm{BCF}$; bioconcentration factor) are given in Table 1 (on a dry biomass basis, db). The mercury contents of the soil samples and fruiting bodies (cap and stipe or the whole fruiting bodies) of the European Cow Bolete $S$. bovinus samples were all found to be less than $1.0 \mathrm{mg} \mathrm{kg}^{-1} \mathrm{db}$.

The mean $\mathrm{Hg}$ concentrations of the fruiting bodies of Suillus bovines revealed slightly elevated $\mathrm{Hg}$ uptake for samples from Pomerania land and Darżlubska Wilderness vicinity compared to the other sites. The mean $\mathrm{Hg}$ in the cap varied from $0.10 \pm 0.06 \mathrm{mg} \mathrm{kg}^{-1} \mathrm{db}$ (Pomerania, Nearshore landscape Park) to $0.79 \pm 0.4 \mathrm{mg} \mathrm{kg}^{-1} \mathrm{db}$ (Pomerania Land, Darżlubska Wilderness site) with $\mathrm{Hg}$ in individual samples ranging from 0.015 to $1.7 \mathrm{mg} \mathrm{kg}^{-1} \mathrm{db}$. Similar mean $\mathrm{Hg}$ in caps values were observed for the Pomerania, Nearshore Landscape Park and Mazovia land, commune of Kościelna Wieczfnia sites $\left(0.10 \pm 0.06\right.$ and $0.11 \pm 0.03 \mathrm{mg} \mathrm{kg}^{-1} \mathrm{db}$, respectively), as well as in the caps from Warmia and Mazury land, Szczytno $\left(0.20 \pm 0.04 \mathrm{mg} \mathrm{kg}^{-1} \mathrm{db}\right)$ and in whole fruiting bodies from Pomerania land, Tuchola Pinewoods, Osowo Leśne $\left(0.21 \pm 0.03 \mathrm{mg} \mathrm{kg}^{-1} \mathrm{db}\right)$. The median mercury concentration of the cap of $S$. bovinus samples ranged from 0.11 to $0.66 \mathrm{mg} \mathrm{kg}^{-1} \mathrm{db}$. In this work, higher $\mathrm{Hg}$ contents were observed in cap compared to the stipes, with Qc/s values ranging from $1.3 \pm 0.2$ to $2.6 \pm 0.6$ with individual Qc/s values ranging from 0.17 to as high as 5.3.

\section{Hg in soils}

The mean $\mathrm{Hg}$ in soil samples ranged from 0.015 $\pm 0.004 \mathrm{mg} \mathrm{kg}^{-1} \mathrm{db}$ (Pomerania land, Tuchola Pinewoods, Osowo Leśne) to $0.031 \pm 0.019 \mathrm{mg} \mathrm{kg}^{-1} \mathrm{db}$ in Warmia and Mazury land, Szczytno). Similar Hg in soil values were observed for the Pomerania land Studnica river valley, the Kępice and Sulęczyno as well as the Warmia and Mazury land Kaszuny sites $(0.025 \pm 0.011,0.025 \pm 0.006$, and 0.025 $\pm 0.003 \mathrm{mg} \mathrm{kg}^{-1} \mathrm{db}$ respectively), as well as for the Pomerania land, Darżlubska Wilderness vicinity and Mazovia land, commune of Kościelna Wieczfnia sites $\left(0.017 \pm 0.003\right.$ and $0.017 \pm 0.014 \mathrm{mg} \mathrm{kg}^{-1} \mathrm{db}$ respectively). The $\mathrm{Hg}$ content in the soil samples ranged from 0.0069 to $0.62 \mathrm{mg} \mathrm{kg}^{-1} \mathrm{db}$ (median values varied from 0.013 to $0.26 \mathrm{mg} \mathrm{kg}^{-1} \mathrm{db}$ ).

\section{Bioconcentration potential}

To assess the potential of mushroom to take-up and sequester elements ( $\mathrm{Hg}$ in this case) in fruiting body, the quotient of $\mathrm{Hg}$ in the mushroom fruiting bodies (cap or stipe or even the whole fruiting body) to the corresponding $\mathrm{Hg}$ in litter/soil layer of the substratum which is defined as BCF or transfer factor (TF) is readily used. In this study, the BCF values ranged from $6.4 \pm 2.2$ to $45 \pm 20$ (individual $B C F$ values ranging from 1.2 to 96 ) for caps and from $3.8 \pm 1.4$ to $29 \pm 11$ (individual BCF values ranging from 1.1 to 49 ) for stipes indicating that $S$. bovinus is a moderate accumulator of mercury (Table 1).

For the range of rather low $\mathrm{Hg}$ concentrations determined in the forest topsoil layer samples in this study, no statistically significant relationship could be observed between $\mathrm{Hg}$ level in soil substrate and $\mathrm{Hg}$ accumulated in fruiting bodies of $S$. bovinus. A positive tendency of an increase in the $\mathrm{Hg}$ content of mushrooms with increase in $\mathrm{Hg}$ levels in soils was observed for a set of mushrooms of genus Leccinum that emerged from soils with a wide range of $\mathrm{Hg}$ content-from low to elevated soil $\mathrm{Hg}$ contents, probably resulting from geogenic anomaly (Falandysz et al. 2015a). 


\section{Hg intake from consumption of $S$. bovinus}

For health concerns, especially considering the dangers of intakes of toxic contaminants such as mercury, it is pertinent to estimate $\mathrm{Hg}$ intakes from food and foodstuff. This allows the evaluation of either the nutritional benefits or toxicological concerns of intakes from consumption of such foods. A mercury RfD of $0.0003 \mathrm{mg} \mathrm{kg}^{-1}$ body mass daily which was set by the US EPA is readily used when evaluating the risks in $\mathrm{Hg}$ intake from foods. Also used in such assessments is the tolerable daily intake rate of $0.00061 \mathrm{mg} \mathrm{kg}^{-1}$ body mass which is derived from the PTWI of $0.0043 \mathrm{mg} \mathrm{kg}^{-1}$ body mass (i.e., $0.26 \mathrm{mg}$ for an individual of $60 \mathrm{~kg}$ body mass) as established by the FAO/WHO (US EPA 1987; JECFA 2010). Literature identifies mushroom meals to be in the range of 100-500 g per meal depending on variables such as mushroom availability (during or out of the mushrooming season) and individual preference. In this study, intake rates of $\mathrm{Hg}$ from consumption of $S$. bovinus was estimated by assuming that an average consumer eats about $300 \mathrm{~g}$ of caps of $S$. bovinus at the site surveyed. The consumption of a meal $300 \mathrm{~g}$ of $S$. bovinus collected at the Mazovia land commune of Kościelna Wieczfnia (site with the lowest mean $\mathrm{Hg}$ in caps of $0.11 \pm 0.03 \mathrm{mg} \mathrm{kg}^{-1}$ $\mathrm{db}$ ) will result in estimated $\mathrm{Hg}$ intake of $0.0033 \mathrm{mg}$ while for the Pomerania land, Darżlubska Wilderness site (site with the highest mean $\mathrm{Hg}$ in cap of $0.79 \pm 0.40 \mathrm{mg} \mathrm{kg}^{-1} \mathrm{db}$ ), this will result in estimated $\mathrm{Hg}$ intake of $0.024 \mathrm{mg}$. These estimated intake values were calculated assuming $90 \%$ moisture content of mushroom and an adult individual of $60 \mathrm{~kg}$ body mass.

These exposure levels will amount to 1.4 to $10 \%$ of the recommended reference dose for caps on consumption of $300 \mathrm{~g}$ of caps only and these are below the $0.24 \mathrm{mg} \mathrm{Hg}$ dose of PTWI, assuming no $\mathrm{Hg}$ from other foods is ingested. Consequently, there is no toxicological concern over $\mathrm{Hg}$ intake from the consumption of $S$. bovinus from the locations investigated in this study.

\section{Target hazard quotient (THQ)}

The EDI and THQ values on the consumption of $S$. bovinus by ALC who consumes a $100 \mathrm{~g}$ meal of caps of S. bovinus (fresh weight) and a HLC who consumes $300 \mathrm{~g}$ of this mushroom for the sites studied (using the range of the data obtained) are presented in Table 2.

Values of EDI ( $\mu \mathrm{g} \mathrm{kg}^{-1}$ fresh weight/day) and THQ for all the sites were generally very low for both ALC and HLC indicating that the consumption of $S$. bovinus does not pose health hazard to consumers. THQ is gaining prominence as one of the parameters used in assessing risk of exposure from food consumption. The THQ values were $<1$ for all sites studied, including the Pomerania land, Puszcza Darżlubska site for which the highest $\mathrm{Hg}$ in caps $\left(1.7 \mathrm{mg} \mathrm{kg}^{-1}\right)$ of this study was observed (Table 2). This indicates that the consumers of $S$. bovinus for the sites investigated are not exposed to hazard risks.

\section{Review of literature on $\mathrm{Hg}$ in fruiting bodies of fungi genus Suillus}

Available literature of $\mathrm{Hg}$ contents for 12 species of fungi genus Suillus are given in Table 3. Data presented in Table 3 include species such as S. bovinus (L.) Roussel, Suillus brevipes (Peck) Kuntze, Suillus cavipes (Opat.) A.H. Sm. \& Thiers, Suillus collinitus (Fr.) Kuntze, Suillus granulatus (L.) Roussel (also called Suillus lactifluus With.), Suillus grevillei (Klotzsch) Singer, Suillus luteus (L.) Roussel, Suillus placidus (Bonord.) Singer, Suillus spraguei (Berk. \& M.A. Curtis) Kuntze (formally called Suillus pictus Kuntze), Suillus

Table 2 Values of estimated daily intakes (EDI) ( $\mu \mathrm{g} / \mathrm{kg}$ fresh weight/day) and target hazard quotient (THQ) of an average level consumer (ALC) and a high level consumer (HLC) of Suillus bovinus mushroom in Poland

\begin{tabular}{lllll}
\hline Site & EDI ALC & EDI HLC & THQ ALC & THQ HLC \\
\hline Pomerania land, Darżlubska Wilderness & $0.0003^{\mathrm{a}-0.0005^{\mathrm{b}}}$ & $0.000128-0.000728$ & $0.00019-0.00113$ & $0.000257-0.001457$ \\
Pomerania land, Nearshore Landscape Park & $0.000005-0.000086$ & $0.000006-0.000011$ & $0.000009-0.000173$ & $0.000013-0.000223$ \\
Pomerania land, Studnica river Valley, Kępice & $0.000001-0.000043$ & $0.000042-0.000055$ & $0.000065-0.000866$ & $0.000083-0.001114$ \\
Pomerania land, Sulęczyno & $0.000003-0.000010$ & $0.000004-0.000013$ & $0.000066-0.000206$ & $0.000085-0.000265$ \\
Pomerania land, Tuchola Pinewoods, Osowo Leśne & $0.000004-0.000008$ & $0.000005-0.000010$ & $0.000086-0.000166$ & $0.000111-0.000214$ \\
Pomerania land, Tuchola Pinewoods, Lubichowo & $0.000005-0.000200$ & $0.000006-0.000025$ & $0.000106-0.000399$ & $0.000137-0.000514$ \\
Warmia and Mazury land, Kaszuny & $0.000006-0.000260$ & $0.000008-0.000033$ & $0.000133-0.000519$ & $0.000171-0.000668$ \\
Warmia and Mazury land, Szczytno & $0.000004-0.000008$ & $0.000005-0.000011$ & $0.000086-0.000173$ & $0.000111-0.000223$ \\
Mazovia land, Commune of Kościelna Wieczfnia, & $0.000018-0.000060$ & $0.000024-0.000077$ & $0.000037-0.000119$ & $0.000047-0.000154$ \\
Mazovia land, Lipowiec Kościelny & $0.000063-0.000330$ & $0.000081-0.000420$ & $0.000126-0.000659$ & $0.000163-0.000848$ \\
Kujawy land, Ciechocinek & $0.000006-0.000126$ & $0.000085-0.000016$ & $0.000133-0.000253$ & $0.000171-0.000325$ \\
\hline
\end{tabular}

\footnotetext{
${ }^{\mathrm{a}}$ Minimum
}

${ }^{\mathrm{b}}$ Maximum 
Table 3 Mercury in mushrooms of the genus Suillus worldwide (mean; mean \pm S.D.; range of the mean values and the overall range-in parentheses, respectively; $\mathrm{mg} \mathrm{kg}^{-1} \mathrm{db}$ ), data adapted to show only two significant figures - where necessary

\begin{tabular}{|c|c|c|c|c|c|}
\hline $\begin{array}{l}\text { Species, year(s), and number } \\
\text { of specimens }\end{array}$ & Region of the world & $\begin{array}{l}\mathrm{Hg} \text { (whole } \\
\text { fruit body) }\end{array}$ & $\mathrm{Hg}$ (caps) & $\mathrm{Hg}$ (stipes) & Reference \\
\hline Suillus bovinus, 1979-80 (1) & Japan, Fukushima & 0.6 & & & Kawai et al. 1986 \\
\hline Suillus bovinus, p.1976 (1) & Europe, Slovenia, Kurešček & 0.14 & & & Byrne et al. 1976 \\
\hline Suillus bovinus, 1994 (15) & Europe, Poland, Kaszuby & & $\begin{array}{l}0.065 \pm 0.026 \\
(0.017-0.13)\end{array}$ & $\begin{array}{l}0.045 \pm 0.023 \\
\quad(0.016-0.10)\end{array}$ & Falandysz et al. 1996 \\
\hline Suillus bovinus, 1995-96 (15) & Europe, Poland, Kaszuby & & $\begin{array}{l}0.32 \pm 0.17 \\
\quad(0.18-0.75)\end{array}$ & $\begin{array}{l}0.16 \pm 0.07 \\
\quad(0.040-0.29)\end{array}$ & Falandysz et al. 2003b \\
\hline Suillus bovinus, 1996-97 (14) & Europe, Poland, Pomerania & & $\begin{array}{l}0.65 \pm 0.50 \\
\quad(0.14-1.8)\end{array}$ & $\begin{array}{l}0.35 \pm 0.18 \\
\quad(0.10-0.65)\end{array}$ & Falandysz et al. 2003a \\
\hline Suillus bovinus, 1997-98 (11) & Europe, Poland, Pomerania & & $\begin{array}{l}0.20 \pm 0.11 \\
\quad(0.090-0.41)\end{array}$ & $\begin{array}{l}0.077 \pm 0.035 \\
\quad(0.038-0.15)\end{array}$ & Falandysz et al. 2004 \\
\hline Suillus bovinus, 1994 (3) & Europe, Poland, Pomerania & & $\begin{array}{l}0.26 \pm 0.02 \\
\quad(0.25-0.28)\end{array}$ & & Falandysz et al. 2001b \\
\hline Suillus bovinus, $(1)^{\mathrm{a}}$ & Europe, Poland & $0.17 \pm 0.02$ & & & Falandysz et al. 2015c \\
\hline Suillus bovinus, 2002 (1) & Asia Minor, Turkey, Izmir & $0.10 \pm 0.01$ & & & $\begin{array}{l}\text { Kardeniz and Yaprak } \\
\quad 2010\end{array}$ \\
\hline Suillus bovinus, 2002 (1) & $\begin{array}{l}\text { Asia Minor, Turkey, } \\
\text { Kurudere }\end{array}$ & $0.050 \pm 0.005$ & & & $\begin{array}{l}\text { Karadeniz and Yarpak } \\
2010\end{array}$ \\
\hline $\begin{array}{l}\text { Suillus bovinus, 1993-2013 } \\
\quad(586)\end{array}$ & Europe, Poland & $0.15-0.23$ & $\begin{array}{r}0.10 \pm 0.06- \\
0.79 \pm 0.40\end{array}$ & $\begin{array}{c}0.083 \pm 0.028- \\
0.51 \pm 0.22\end{array}$ & This study \\
\hline Suillus brevipes, p.2006 (1) & China, Sichuan, Liangshan & 0.12 & & & Zhang et al. 2006 \\
\hline Suillus cavipes, p.2012 (22) & $\begin{array}{l}\text { N. America, New } \\
\text { Brunswick }\end{array}$ & $\begin{aligned} & 0.20 \pm 0.10 \\
&(0.10-5.1)\end{aligned}$ & & & Nasr et al. 2012 \\
\hline Suillus collinitus, p.2006 (14) & Europe, Italy, R. Emilia & 0.18 & & & Cocchi et al. 2006 \\
\hline Suillus collinitus, 2013-14 (52) & China, Yunnan, Yuxi & & $0.089-0.42$ & $0.040-0.20$ & Cocchi et al. 2006 \\
\hline $\begin{array}{l}\text { Suillus granulatus, 1967/1974 } \\
\quad \text { (5) }\end{array}$ & Europe, Germany - south & $0.37(0.25-0.65)$ & & & Seeger and Nützel 1976 \\
\hline Suillus granulatus, 1990-99 (2) & $\begin{array}{l}\text { Europe, Slovakia, Middle } \\
\text { Spiš }\end{array}$ & 5.7 & & & $\begin{array}{l}\text { Zimmermannová et al. } \\
2001\end{array}$ \\
\hline $\begin{array}{l}\text { Suillus granulatus, 1993-94 } \\
\text { (15) }\end{array}$ & Europe, Poland, Kaszuby & & $\begin{array}{l}0.18 \pm 0.08 \\
\quad(0.055-0.33)\end{array}$ & $\begin{array}{l}0.070 \pm 0.029 \\
\quad(0.037-0.14)\end{array}$ & Falandysz et al. 1996 \\
\hline Suillus granulatus, 2005 (1) & Europe, Poland, Łódź & 0.24 & 0.32 & 0.16 & Szynkowska et al. 2008 \\
\hline Suillus granulatus, p.2006 (1) & China, Sichuan, Liangshan & 0.28 & & & Zhang et al. 2006 \\
\hline Suillus granulatus, p.2006 (17) & Europe, Italy, R. Emilia & 0.29 & & & Cocchi et al. 2006 \\
\hline Suillus granulatus, 1993 (1) & Europe, Hungary & $2.5 \pm 0.0$ & & & Vetter and Berta 1997 \\
\hline Suillus granulatus, 2002 (52) & Europe, Poland & & $0.38-0.41$ & $0.068-0.14$ & Saba et al. $2016 b$ \\
\hline Suillus granulatus, 2003 (1) & Europe, Sweden, Forsmark & 0.069 & & & Johanson et al. 2004 \\
\hline Suillus grevillei, 1967-74 (7) & Europe, Germany - south & $0.22(0.08-0.45)$ & & & Seeger and Nützel, 1976 \\
\hline Suillus grevillei, 1990-99 (4) & $\begin{array}{l}\text { Europe, Slovakia, Middle } \\
\text { Spiš }\end{array}$ & 4.8 & & & $\begin{array}{l}\text { Zimmermannová et al. } \\
2001\end{array}$ \\
\hline Suillus grevillei, 1997-98 (15) & Europe, Poland, Pomerania & & $\begin{array}{l}0.22 \pm 0.06 \\
\quad(0.080-0.32)\end{array}$ & $\begin{array}{l}0.13 \pm 0.05 \\
\quad(0.065-0.24)\end{array}$ & Falandysz et al. 2004 \\
\hline $\begin{array}{l}\text { Suillus grevillei, 2000-2006 } \\
\quad(121)\end{array}$ & Europe, Poland & & $\begin{array}{r}0.26 \pm 0.08- \\
0.50 \pm 0.10\end{array}$ & $\begin{array}{c}0.089 \pm 0.026- \\
0.16 \pm 0.07\end{array}$ & Chudzyński et al. 2009 \\
\hline Suillus grevillei, 1993 (1) & Europe, Hungary & $0.10 \pm 0.00$ & & & Vetter and Berta 1997 \\
\hline Suillus grevillei, 2000 (1) & Asia, Katun Nature Resrve & & 0.1 & 0.1 & Gorbunova et al. 2009 \\
\hline Suillus grevillei, p.2011 (1) & Europe, Switzerland & 0.38 & & & Rieder at al. 2011 \\
\hline Suillus grevillei, p.2012 (40) & N. America, New Brunswick & $\begin{array}{r}0.56 \pm 0.80 \\
(0.30-2.9)\end{array}$ & & & Nasr et al. 2012 \\
\hline Suillus luteus, 1967 (1) & Europe, Germany — south & 0.15 & & & Seeger and Nützel 1976 \\
\hline Suillus luteus, 1990-99 (10) & $\begin{array}{l}\text { Europe, Slovakia, Middle } \\
\text { Spišs }\end{array}$ & 5.8 & & & $\begin{array}{l}\text { Zimmermannová et al. } \\
2001\end{array}$ \\
\hline Suillus luteus, 1997-98 (15) & Europe, Poland, Pomerania & & $\begin{array}{l}0.13 \pm 0.06 \\
\quad(0.061-0.23)\end{array}$ & $\begin{array}{l}0.054 \pm 0.037 \\
\quad(0.017-0.16)\end{array}$ & Falandysz et al. 2004 \\
\hline
\end{tabular}


Table 3 (continued)

\begin{tabular}{|c|c|c|c|c|c|}
\hline $\begin{array}{l}\text { Species, year(s), and number } \\
\text { of specimens }\end{array}$ & Region of the world & $\begin{array}{l}\mathrm{Hg} \text { (whole } \\
\text { fruit body) }\end{array}$ & Hg (caps) & $\mathrm{Hg}$ (stipes) & Reference \\
\hline Suillus luteus, 1995-96 (15) & Europe, Poland, Kaszuby & & $\begin{array}{l}0.19 \pm 0.07 \\
\quad(0.12-0.39)\end{array}$ & $\begin{array}{l}0.088 \pm 0.042 \\
\quad(0.041-0.13)\end{array}$ & Falandysz et al. 2003b \\
\hline Suillus luteus, p.2006 (17) & Europe, Italy & 0.28 & & & Cocchi et al. 2006 \\
\hline Suillus luteus, 1995 (14) & Europe, Sweden & & $0.17 \pm 0.07$ & $0.074 \pm 0.014$ & Saba et al. 2016a \\
\hline Suillus luteus, 2012-13 (30) & Europe, Belarus & & $0.090-0.15$ & 0.0380 .073 & Saba et al. 2016a \\
\hline Suillus luteus, 1997-98 (96) & Europe, Poland, Mazury & & $\begin{array}{l}0.14 \pm 0.03 \\
\quad(0.080-0.18)\end{array}$ & $\begin{array}{l}0.043 \pm 0.015 \\
\quad(0.019-0.079)\end{array}$ & Falandysz et al. 2002 \\
\hline Suillus luteus, 1994 (3) & Europe, Poland, Pomerania & & $\begin{array}{l}0.34 \pm 0.05 \\
\quad(0.29-0.38)\end{array}$ & & Falandysz et al. 2001b \\
\hline Suillus luteus, 2002-07 (383) & Europe, Poland & & $\begin{array}{c}0.095 \pm 0.082- \\
0.28 \pm 0.07\end{array}$ & $\begin{array}{c}0.045 \pm 0.018- \\
0.13 \pm 0.03\end{array}$ & Chudzyński et al. 2011 \\
\hline Suillus luteus, 2000-2010 (821) & Europe, Poland & $0.11-0.86(342)$ & $0.13-0.33$ & $0.038-0.096$ & Saba et al. 2016a \\
\hline Suillus luteus, 1995-2006 (529) & Europe, Poland & $0.11-0.30$ & $0.29(15)$ & & Saba et al. 2016a \\
\hline Suillus luteus, p.2011 (1) & Europe, Switzerland & 0.51 & & & Rieder at al. 2011 \\
\hline Suillus placidus 1967 (1) & Europe, Germany - south & 0.12 & & & Seeger and Nützel 1976 \\
\hline Suillus spraguei, 2014 (16) & China, Yunnan, Pu'er & & 0.42 & 0.14 & Falandysz et al. 2016 \\
\hline Suillus spraguei, 2014 (19) & China, Yunnan, Yuxi & & 0.22 & 0.10 & Falandysz et al. 2016 \\
\hline $\begin{array}{l}\text { Suillus variegatus, 1967/1974 } \\
\text { (4) }\end{array}$ & Europe, Germany - south & $0.22(0.16-0.30)$ & & & Seeger and Nützel, 1976 \\
\hline Suillus variegatus, 1995-96 (14) & Europe, Poland, Kaszuby & & $\begin{array}{l}0.065 \pm 0.033 \\
\quad(0.019-0.12)\end{array}$ & $\begin{array}{l}0.029 \pm 0.014 \\
\quad(0.013-0.060)\end{array}$ & Falandysz et al. 2003b \\
\hline Suillus variegatus, 1997-98 (48) & Europe, Poland, Mazury & & $\begin{array}{l}0.26 \pm 0.08 \\
\quad(0.12-0.43)\end{array}$ & $\begin{array}{l}0.084 \pm 0.029 \\
\quad(0.050-0.16)\end{array}$ & Falandysz et al. 2002 \\
\hline $\begin{array}{l}\text { Suillus variegatus, 1977-1999 } \\
\quad \text { (10) }\end{array}$ & Europe, Finland & 0.24 & & & Pelkonen et al. 2008 \\
\hline Suillus variegatus, p.2004 & Europe, Bohemia & $0.24 \pm 0.04$ & & & Řanda and Kučera 2004 \\
\hline Suillus variegatus, 2003 (3) & Europe, Sweden, Forsmark & $0.14-2.0$ & & & Johanson et al. 2004 \\
\hline $\begin{array}{l}\text { Suillus variegatus, 1998-2013 } \\
\quad \text { (198) }\end{array}$ & Europe, Poland & $0.087(15)$ & $\begin{array}{c}0.094 \pm 0.018- \\
0.27 \pm 0.10\end{array}$ & $\begin{array}{r}0.045 \pm 0.08- \\
0.18 \pm 0.12\end{array}$ & Saba et al. $2016 \mathrm{~b}$ \\
\hline Suillus viscidus, 1967/1974 (3) & Europe, Germany - south & $0.27(0.20-0.35)$ & & & Seeger and Nützel, 1976 \\
\hline Suillus viscidus, 1996 & Europe, East Bohemian & $0.80 \pm 0.21$ & & & Cibulka et al. 1996 \\
\hline Suillus viscidus, 1996 & Europe, West Bohemian & $1.0 \pm 0.6$ & & & Cibulka et al. 1996 \\
\hline Suillus viscidus, 1996 & Europe, North Bohemian & $0.76 \pm 0.26$ & & & Cibulka et al. 1996 \\
\hline Suillus viscidus, p.2012 (12) & $\begin{array}{l}\text { N. America, New } \\
\text { Brunswick }\end{array}$ & $\begin{array}{l}0.33 \pm 0.19 \\
\quad(0.15-0.77)\end{array}$ & & & Nasr et al. 2012 \\
\hline
\end{tabular}

${ }^{\text {a }}$ CS-M-1 (dried fruiting bodies of mushroom Cow Bolete Suillus bovinus), produced by the Institute of Nuclear Chemistry and Technology in Warsaw, Poland); unpublished (own study)

variegatus (Sw.) Richon \& Roze, and Suillus viscidus (L.) Roussel (formally called Suillus aeruginascens (Species Fungorum 2015). In several studies with varying numbers of specimens and from diverse sampling sites/locations, the typical content of $\mathrm{Hg}$ in Suillus mushrooms as reviewed (Table 3) was $<1 \mathrm{mg} \mathrm{kg}^{-1} \mathrm{db}$ for whole fruiting bodies, $<1 \mathrm{mg} \mathrm{kg}^{-1} \mathrm{db}$ for caps, and $<0.5 \mathrm{mg} \mathrm{kg}^{-1} \mathrm{db}$ for stipes. When compared to the "typical content," a substantially elevated $\mathrm{Hg}$ content have been observed in individual samples of three species collected from sites polluted with $\mathrm{Hg}$. Due to the operation of a mercury smelter and a copper smelter in the Middle Spiš land in the Slovakia (Central Europe), high Hg levels were reported in Suillus species from this site-
$5.7 \mathrm{mg} \mathrm{kg}^{-1} \mathrm{db}$ in Suillus granulatus, $4.8 \mathrm{mg} \mathrm{kg}^{-1} \mathrm{db}$ in Suillus grevillei, and $5.8 \mathrm{mg} \mathrm{kg}^{-1} \mathrm{db}$ in Suillus luteus (Table 3). An elevated $\mathrm{Hg}$ content of $2.5 \mathrm{mg} \mathrm{kg}^{-1} \mathrm{db}$ (which is above the "typical level") was also reported for S. granulatus from a location with no known history of $\mathrm{Hg}$ pollution (substrate is the possible source) in Hungary. For majority of the Suillus mushrooms reviewed and with relatively large datasets, regardless of the origin/source of the specimens (mostly European in this review), the $\mathrm{Hg}$ content in fruiting body and its morphological parts was well below $0.5 \mathrm{mg} \mathrm{kg}^{-1} \mathrm{db}$. Data available on $\mathrm{Hg}$ in Suillus mushrooms and in their soil substrate polluted (from a point source or from global depositions) with $\mathrm{Hg}$ could imply that they are able to 
respond in a dose-response manner to elevated exposure (via soil substrata) to $\mathrm{Hg}$ regardless of the origin of the $\mathrm{Hg}-$ geogenic (natural) or anthropogenic (non-ferrous smelters). The decades of global $\mathrm{Hg}$ emissions from anthropogenic sources and subsequent pollution of forest topsoil with $\mathrm{Hg}$ seem to have had little effect on the levels of $\mathrm{Hg}$ accumulated in fruiting bodies by mycorrhizal fungi of genus Suillus. Nevertheless, no data are available on $\mathrm{Hg}$ contents of mushrooms from the pre-industrial era.

\section{Conclusion}

This study has shown that $S$. bovinus collected from sites considered as non-contaminated with $\mathrm{Hg}$ in Poland contain low $\mathrm{Hg}$ levels that varied spatially in both the caps and the stipes. The low Hg contents of the substrate suggest some airborne $\mathrm{Hg}$ deposition and low geogenic contamination with mercury and that for less contaminated soils which can be found for majority of the forested areas in Poland, the $S$. bovinus is a moderate accumulator of $\mathrm{Hg}$. When compared with the established limits of $\mathrm{Hg}$ intake from foods, the consumption of $S$. bovinus does not pose toxicological concerns.

Acknowledgments Technical assistance by Joanna Bułat, Anna Dryżałowska, Anna Linda, Karolina Lubiejewska, Michalina Mazur, Aleksandra Mostrąg, Arleta Naczk, Daniela Orłowska, Maria Ulman, and Wioletta Witka-Jeżewska is acknowledged.

Open Access This article is distributed under the terms of the Creative Commons Attribution 4.0 International License (http:// creativecommons.org/licenses/by/4.0/), which permits unrestricted use, distribution, and reproduction in any medium, provided you give appropriate credit to the original author(s) and the source, provide a link to the Creative Commons license, and indicate if changes were made.

\section{References}

Alonso J, Salgado JM, Garcia MA, Melgar MJ (2000) Accumulation of mercury in edible macrofungi: influence of some factors. Arch Environ Contam Toxicol 38:158-162

Árvay J, Tomáša J, Hauptvogl M, Kopernická M, Kováčik A, Bajčan D, Massányi P (2014) Contamination of wild-grown edible mushrooms by heavy metals in a former mercury-mining area. J Environ Sci Health Part B 49:815-827

Bennett DH, Kastenberg WE, McKone TE (1999) A multimedia, multiple pathway risk assessment of atrazine: the impact of age differentiated exposure including joint uncertainty and variability. Reliability Eng Sys Saf 63:185-198

Brzostowski A, Falandysz J, Jarzyńska G, Zhang D (2011) Bioconcentration potential of metallic elements by Poison Pax (Paxillus involutus) mushroom. J Environ Sci Health Part A 46: 378-393

Byrne AR, Ravnik V, Kosta L (1976) Trace element concentrations in higher fungi. Sci Total Environ 6:65-78
Chien LC, Hung TC, Choang KY, Choang KY, Yeh CY, Meng PJ, Shieh MJ, Han BC (2002) Daily intake of TBT, Cu, Zn, Cd and As for fishermen in Taiwan. Sci Total Environ 285:177-185

Chojnacka A, Jarzyńska G, Drewnowska M, Nnorom IC, Falandysz J (2012) Yellow-cracking Boletes (Xerocomus subtomentosus) mushrooms: content and potential to sequestrate mercury. J Environ Sci Health Part A 47:2094-3011

Chudzyński K, Bielawski L, Falandysz J (2009) Mercury bioconcentration potential of Larch Bolete, Suillus grevillei, mushroom. Bull Environ Contam Toxicol 83:275-279

Chudzyński K, Jarzyńska G, Stefańska A, Falandysz J (2011) Mercury content and bio-concentration potential of Slippery Jack, Suillus luteus, mushroom. Food Chem 125:986-990

Cibulka J, Šišák L, Pulkrab K, Miholová D, Száková J, Fuciková A, Slámová A, Stehulová L, Barláková S (1996) Cadmium, lead, mercury and caesium levels in wild mushrooms and forest berries from different localities of the Czech Republic. Sci Agric Bohem 27:113129

Cocchi L, Vescovi L, Petrini LE, Petrini O (2006) Heavy metals in edible mushrooms in Italy. Food Chem 98:277-284

Crane S, Dighton J, Barkay T (2010) Growth responses to and accumulation of mercury by ectomycorrhizal fungi. Fungal Biol 114:873880

Demers JD, Driscoll CT, Fahey TJ, Yavitt JB (2007) Mercury cycling in litter and soil in different forest types in the Adirondack region, New York, USA. Ecol Applic 17:1341-1351

Drewnowska M, Jarzyńska G, Kojta AK, Falandysz J (2012) Mercury in European Blusher, Amanita rubescens, mushroom and soil bioconcentration potential and intake assessment. J Environ Sci Health Part B 47:466-474

Drewnowska M, Nnorom IC, Falandysz J (2014) Mercury in the Tawny Grisette, Amanita vaginata $\mathrm{Fr}$ and soil below the fruiting bodies. $\mathrm{J}$ Environ Sci Health Part B 49:521-526

Falandysz J (2014) Distribution of mercury in Gypsy Cortinarius caperatus mushrooms from several populations: an efficient accumulator species and estimated intake of element. Ecotoxicol Environ Saf 110:68-72

Falandysz J (2016) Mercury bio-extraction by fungus Coprinus comatus: a possible bioindicator and mycoremediator of polluted soils. Environ Sci Poll Res 23, doi. 10.1007/s11356-015-5971-8

Falandysz J, Bielawski L (2001) Mercury content of wild edible mushrooms collected near the town of Augustów. Pol J Environ Sci 10: $67-71$

Falandysz J, Bielawski L (2007) Mercury and its bioconcentration factors in Brown Birch Scaber Stalk (Leccinum scabrum) from various sites in Poland. Food Chem 105:635-640

Falandysz J, Borovička J (2013) Macro and trace mineral constituents and radionuclides in mushrooms - health benefits and risks. Appl Microbiol Biotechnol 97:477-501

Falandysz J, Brzostowski A (2007) Mercury and its bioconcentration factors in Poison Pax (Paxillus involutus) from various sites in Poland. J Environ Sci Health Part A 42:1095-1100

Falandysz J, Drewnowska M (2015) Distribution of mercury in Amanita fulva (Schaeff) Secr mushrooms: accumulation, loss in cooking and dietary intake. Ecotoxicol Environ Saf 115:49-54

Falandysz J, Gucia M (2008) Bioconcentration factors of mercury by Parasol Mushroom (Macrolepiota procera). Environ Geochem Health 30:121-125

Falandysz J, Bona H, Danisiewicz D (1994) Silver content of wild-grown mushrooms from northern Poland. Z Lebensm Unters-Forsch 199: $222-224$

Falandysz J, Marcinowicz A, Chwir A (1996) Rtęć w jadalnych grzybach z terenu lasów kościerskich i Mierzei Wiślanej Roczn. Państw Zakł Hig 47:205-210

Falandysz J, Gucia M, Frankowska A, Kawano M, Skwarzec B (2001a) Total mercury in wild mushrooms and underlying soil substrate 
from the city of Umeå and its surroundings, Sweden. Bull Environ Contam Toxicol 67:763-770

Falandysz J, Szymczyk K, Ichihashi H, Bielawski L, Gucia M, Frankowska A, Yamasaki S (2001b) ICP/MS and ICP/AES elemental analysis (38 elements) of edible wild mushrooms growing in Poland. Food Addit Contam 18:503-513

Falandysz J, Bielawski L, Kannan K, Gucia M, Lipka K, Brzostowski A (2002) Mercury in wild mushrooms and underlying soil substrate from the great lakes land in Poland. J Environ Monit 4: 473-476

Falandysz J, Brzostowski A, Kawano M, Kannan K, Puzyn T, Lipka K (2003a) Concentrations of mercury in wild growing higher fungi and underlying substrate near lake Wdzydze, Poland. Water Air Soil Pollut 148:127-137

Falandysz J, Kawano M, Świeczkowski A, Brzostowski A, Dadej M (2003b) Total mercury in wild-grown higher mushrooms and underlying soil from Wdzydze Landscape Park, Northern Poland. Food Chem 81:21-26

Falandysz J, Gucia M, Brzostowski A, Kawano M, Bielawski L, Frankowska A, Wyrzykowska B (2003c) Content and bioconcentration of mercury in mushrooms from northern Poland. Food Addit Contam 20:247-253

Falandysz J, Lipka K, Kawano M, Brzostowski A, Dadej M, Jędrusiak A, Puzyn T (2003d) Mercury content and its bioconcentration factors at Łukta and Morag, Northeastern Poland. J Agric Food Chem 51: 2832-2836

Falandysz J, Jędrusiak A, Lipka K, Kurunthachalam K, Kawano M, Gucia M, Brzostowski A, Dadej M (2004) Mercury in wild mushrooms and underlying soil substrate from Koszalin, North-central Poland. Chemosphere 54:461-466

Falandysz J, Kunito T, Kubota R, Lipka K, Mazur A, Falandysz JJ, Tanabe S (2007) Selected elements in fly agaric Amanita muscaria. J Environ Sci Health Part A 42:1615-1623

Falandysz J, Kojta AK, Jarzyńska G, Drewnowska A, Dryżałowska A, Wydmańska D, Kowalewska I, Wacko A, Szlosowska M, Kannan K, Szefer P (2012a) Mercury in Bay Bolete Xerocomus badius: bioconcentration by fungus and assessment of element intake by humans eating fruiting bodies. Food Addit Contam Part A 29: 951-961

Falandysz J, Widzicka E, Kojta AK, Jarzyńska G, Drewnowska M, Danisiewicz-Czupryńska D, Dryżałowska A, Lenz E, Nnorom IC (2012b) Mercury in Common Chanterelles mushrooms: Cantharellus spp. update. Food Chem 133:842-850

Falandysz J, Mazur A, Drewnowska M, Kojta AK, Jarzyńska G, Dryżałowska A, Nnorom IC (2013) Mercury in fruiting bodies of Dark Honey Fungus (Armillaria solidipes) and beneath substratum soils collected from spatially distant areas. J Sci Food Agric 93:853858

Falandysz J, Dryżałowska A, Saba M, Wang J, Zhang D (2014a) Mercury in the fairy-ring of Gymnopus erythropus (Pers) and Marasmius dryophilus (Bull) P Karst mushrooms from the Gongga Mountain, Eastern Tibetan Plateau. Ecotoxicol Environ Saf 104:18-22

Falandysz J, Krasińska G, Pankavec S, Nnorom IC (2014b) Mercury in certain Boletus mushrooms from Poland and Belarus. J Environ Sci Health Part B 49:690-695

Falandysz J, Zhang J, Wang Y, Krasińska G, Kojta A, Saba M, Shen T, Li T, Liu H (2015a) Evaluation of the mercury contamination in mushrooms of genus Leccinum from two different regions of the world: accumulation, distribution and probable dietary intake. Sci Total Environ 537:470-478

Falandysz J, Zalewska T, Krasińska G, Apanel A, Wang Y, Pankavec S (2015b) Evaluation of the radioactive contamination in fungi genus Boletus in the region of Europe and Yunnan Province in China. Appl Microbiol Biotechnol 99:8217-8224
Falandysz J, Zhang J, Wang Y, Saba M, Krasińska G, Wiejak A, Li T (2015c) Evaluation of the mercury contamination in Fungi genus Boletus species from the latosols and lateritic red earths and red and yellow earths in region of the circum-Pacific mercuriferous belt in southwestern China. Plos One 10(11):e0143608. doi:10.1371/ journal.pone. 0143608

Gorbunova LA, Koutzenogii KP, Koval'skaya GA, Chankina OV, Savchenko TI (2009) Elemental composition of mushrooms from Gorny Altai. Contemp Problems Ecol 2:46-50

Gucia M, Jarzyńska G, Rafał E, Roszak M, Kojta AK, Osiej I, Falandysz J (2012) Multivariate analysis of mineral constituents of edible Parasol Mushroom (Macrolepiota procera) and soils beneath fruiting bodies collected from Northern Poland. Environ Sci Poll Res 19:416-431

Jarzyńska G, Falandysz J (2011) The determination of mercury in mushrooms by CV-AAS and ICP-AES techniques. J Environ Sci Health Part A 46:569-573

JECFA 2010. Joint FAO/WHO Expert Committee on Food Additives Seventy-second meeting Rome, 16-25 February 2010 Summary and Conclusions JECFA/72/SC Food and Agriculture Organization of the United Nations World Health Organization Issued 16th March 2010 whqlibdoc.who.int/trs/WHO_TRS 959 eng.pdf (accessed 310315)

Johanson KJ, Nikolova I, Taylor AFS, Vinichuk MN (2004) Uptake of elements by fungi in the Forsmark area. Technical Report TR-04026 Swedish Nuclear Fuel and Waste Management Co Stockholm, Sweden

Karadeniz Ō, Yarpak G $(2010){ }^{137} \mathrm{Cs},{ }^{40} \mathrm{~K}$, alkali-alkaline earth element and heavy metal concentrations in wild mushrooms from Turkey. J Radiol Nucl Chem 285:611-619

Kawai H, Sugahara T, Matsuzawa M, Sumiyashiki K, Aoyagi Y, Hosogai Y (1986) Mineral contents in edible mushrooms. Nippon Shokuhin Kogyo Gakkaishi 33:250-255

Kojta A, Jarzyńska G, Falandysz J (2012) Mineral composition and heavy metal accumulation capacity of Bay Bolete (Xerocomus badius) fruiting bodies collected near a former gold and copper mining area. J Geochem Expl 121:76-82

Kojta AK, Wang Y, Zhang J, Li T, Saba M, Falandysz J (2015) Mercury contamination of Fungi genus Xerocomus in the Yunnan Province in China and the region of Europe. J Environ Sci Health Part A 50: $1342-1350$

Krasińska G, Falandysz J (2015) Mercury in Hazel Bolete Leccinum griseum and soil substratum: distribution, bioconcentration and probable dietary exposure. J Environ Sci Health Part A 50:1259 1264

Krasińska G, Falandysz J (2016) Mercury in Orange Birch Bolete Leccinum versipelle and soil substratum: bio-concentration by mushroom and probable dietary intake by consumers. Environ Sci Poll Res 23:860-869

McLaughlin MJ, Parker DR, Clarke JM (1999) Metals and micronutrients - food safety issues. Field Crops Res 60:143-163

Melgar MJ, Alonso J, Garcia MÁ (2009) Mercury in edible mushrooms and soil: bioconcentration factors and toxicological risk. Sci Total Environ 407:5328-5334

Mleczek M, Siwulski M, Mikołajczak P, Gasiecka M, Sobieralski K, Szymańczyk M, Goliński P (2015) Content of selected elements in Boletus badius fruiting bodies growing in extremely polluted wastes. J Environ Sci Health Part A 50:767-775

Nasr N, Arp PA (2011) Hg concentrations and accumulations in fungal fruiting bodies, as influenced by forest soil substrates and moss carpets. Appl Geochem 26:1905-1917

Nasr N, Malloch DW, Arp PA (2012) Quantifying Hg within ectomycorrhizal fruiting bodies, from emergence to senescence. Fungal Biol 116:1163-1177

Nnorom IC, Jarzyñska G, Drewnowska M, Kojta AK, Pankavec S, Falandysz J (2013) Trace elements in sclerotium of Pleurotus 
tuber-regium (Ósu) mushroom-dietary intake and risk in Southeastern Nigeria. J Food Comp Anal 29:73-81

Pelkonen R, Alfthan G, Järvinen. O (2008) Element concentrations in wild edible mushrooms in Finland. The Finnish Environment 25/ 2008 Finnish Environment Institute, vol 25. SYKE Edita Publishing Ltd, Helsinki, p 21

Ralston NVC, Raymond LJ (2010) Dietary selenium's protective effects against methylmercury toxicity. Toxicology 278:112-123

Řanda Z, Kučera J (2004) Trace elements in higher fungi (mushrooms) determined by activation analysis. J Radioanal Nucl Chem 259:99-107

Rieder SR, Brunner I, Horvat M, Jacobs A, Frey B (2011) Accumulation of mercury and methylmercury by mushrooms and earthworms from forest soils. Environ Pollut 159:2861-2869

Saba M, Falandysz J, Nnorom IC (2016a) Accumulation and distribution of mercury in fruiting bodies by fungus Suillus luteus foraged in Poland, Belarus and Sweden. Environ Sci Poll Res 23:2749-2757

Saba M, Falandysz J, Nnorom IC (2016b) Evaluation of vulnerability of Suillus variegatus and Suillus granulatus mushrooms' to sequester mercury in fruiting bodies. J Environ Sci Health Part B 51. doi:10. 1080/03601234.2016.1170552

Sarikurkcu C, Tepe B, Kocak MS, Uren MC (2015) Metal concentration and antioxidant activity of edible mushrooms from Turkey. Food Chem 175:549-555

Seeger R, Nützel M (1976) Quecksilbergehalt der Pilze. Z Lebensm Unters-Forsch 160:303-312

Svoboda L, Kalač P (2003) Contamination of two edible Agaricus spp. mushrooms growing in a town with cadmium, lead, and mercury. Bull Environ Contam Toxicol 71:123-130

Szynkowska MI, Pawlaczyk A, Albiñska J, Paryjczak T (2008) Comparison of accumulation ability of toxicologically important metals in caps and stalks in chosen mushrooms. Polish J Chem 82:313-319

Tel G, Çavdar H, Deveci E, Öztürk M, Duru ME, Turkoğlub A (2014) Minerals and metals in mushroom species in Anatolia. Food Addit Contam B 7:226-231
Tüzen M, Ozdemir M, Demirbas A (1998) Study of heavy metals in some cultivated and uncultivated mushrooms of Turkish origin. Food Chem 63:247-251

UNEP. Mercury-time to act. United Nations Environmental Programme, 2013. http://www.unep.org/PDF/PressReleases/ Mercury_TimeToAct.pdf

US EPA (1987) Peer workshop on mercury issues. October 26-27, 1987, Summary Report. Environmental Criteria and Assessment Office, US Environment Protection Agency Cincinnati, $\mathrm{OH}$.

US EPA (1997) Mercury study report to Congress, health effects of mercury and mercury compounds, vol V Environmental Protection agency, Washington (DC), United States, 1997, EPA-452/R-97-007

USEPA (2002) Region 9, Preliminary Remediation Goals US Environmental Protection Agency, (http://www.epa.Gov/region09/ waste/sfund/prg)

USEPA (US Environmental Protection Agency) (2000) Risk-based concentration table. Philadelphia PA: USEPA, Washington, DC

Vetter J, Berta E (1997) Mercury content of some wild edible mushrooms. Z Lebensm Unters-Forsch 225:316-20.

Wang X, Sato T, Xing B, Tao S (2005) Health risk of heavy metals to the general public in Tianjin, China via consumption of vegetables and fish. Sci Total Environ 350:28-37

Wiejak A, Wang Y, Zhang J, Falandysz J (2014) Bioconcentration potential and contamination with mercury of pantropical mushroom Macrocybe gigantea. J Environ Sci Health Part B 49: 811-814

Zhang D, Gao J, Zheng Y, Li D (2006) Heavy metal content of 9 wild mushrooms growing in Liangshan, Sichuan Chi. J Appl Environ Biol 12:348-351

Zimmermannová N, Svoboda L, Kalač P (2001) Mercury, cadmium, lead and copper contents in fruiting bodies of selected edible mushrooms in contaminated Middle Spiš region, Slovakia. Ekologia (Bratislavia) 20:440-446 